\title{
EXCHANGE OF IgM AND ALBUMIN BETWEEN PLASMA AND SYNOVIAL FLUID IN RHEUMATOID ARTHRITIS
}

\author{
BY \\ D. L. BROWN, A. G. COOPER,* AND R. BLUESTONE $\dagger$ \\ Departments of Haemotology and Medicine, Royal Postgraduate Medical School, London
}

Most of the plasma proteins have been identified in normal synovial fluid (Schur and Sandson, 1963; Ropes and Bauer, 1953) but they are usually present in lower concentrations than those found in the plasma (Ropes and Bauer, 1953; Pekin and Zvaifler, 1964; Sundblad, Jonsson, and Nettelbladt, 1961). The higher molecular weight proteins, such as IgM macroglobulins, $a_{2}$-macroglobulin, and fibrinogen, may not always be detectable. This synovial fluid protein pattern is altered in rheumatoid arthritis so that relatively greater concentrations of the high molecular weight components are present and quantitatively the constituent proteins more closely resemble plasma (Wilkinson and Jones, 1964; Perlmann, Ropes, Kaufmann, and Bauer, 1954; Schmid and MacNair, 1956; Vaughan, Jacox, and Noell, 1968).

Recent studies (Rodnan, Eisenbeis, and Creighton, 1963; Hannestad and Mellbye, 1967; Barnett, Bienenstock, and Bloch, 1966) show similar titres for rheumatoid factor in plasma and synovial fluid, usually with slightly higher titres in plasma, or less commonly higher titres in synovial fluid. However, the precise distribution of rheumatoid factor IgM between plasma and synovial fluid can be only approximated by serological titration.

There have been few reports (Rodnan and Maclachlan, 1960; Kuipers, Francke, and Robert, 1956; Ahlström, Gedda, and Hedberg, 1956; Oeff, 1960) of dynamic studies of the distribution of proteins between synovial fluid and plasma. This investigation is an attempt to follow the metabolism and distribution of radioiodinated IgM in the plasma and synovial fluid of six patients with rheumatoid arthritis, using a group of highly purified cold agglutinins as a source of IgM macroglobulin. IgM was chosen because of its high molecular weight, and its rele-

*Present address: Blood Research Laboratory, Naval Hospital, Chelsea, Massachusetts.

+Present address: School of Medicine, The Center for the Health Sciences, Los Angeles, California vance to rheumatoid factor, which is usually an IgM immunoglobulin. Four of these patients received iodinated albumin to compare the behaviour of high and low molecular weight proteins during the same period of study. Information obtained here allows certain conclusions about the exchange of proteins across the synovial membrane.

Patients, Material, and Methods

\section{Purification of IgM Cold Agglutinin}

Cold agglutinins were purified from the sera of patients with chronic cold haemagglutinin disease by the methoo of Cooper (1968).

Examination of these purified cold agglutinins by cellu lose acetate electrophoresis, immunoelectrophoresis, and Ouchterlony immunodiffusion showed the presence of electrophoretically homogenous, type kappa IgM immunoglobulins.

\section{Albumin Preparation}

Purified lyophilyzed human albumin was obtained commercially.*

\section{Iodination of Proteins}

IgM cold agglutinin and albumin were iodinated with ${ }^{125}$ I or ${ }^{131}$ I by the method of McFarlane (1963) with modifications recommended by Helmkamp, Contreras, and Bale (1967). The degree of iodination was such that there was on an average less than 0.5 atoms of iodine per IgM molecule and less than 1.0 atoms per albumin molecule. Radioactivity in the iodinated preparations was at least 99.7 per cent, precipitable by TCA. Equal volumes of iodinated cold agglutinin IgM and normal serum were mixed and a small aliquot of this was examined by cellulose acetate electrophoresis. The strip was stained and the radio-activity of $2 \mathrm{~mm}$. segments determined. All the radioactivity occurred as a sharp peak at a point corresponding to the $\beta-\gamma$ region of the stained strip, which also corresponded to the cold agglutinin component in the original serum from the patient with chronic cold haemagglutinin disease.

\footnotetext{
*Hoechst Pharmaceuticals, Behringwerke, Marburg, Germany.
} 
IgM and Albumin Quantitation

Total IgM and albumin concentrations in serum and synovial fluid were estimated by the single radial immunodiffusion technique of Mancini, Carbonara, and Heremans (1965).

An experiment was performed to investigate the possible interference by synovial fluid with the diffusion of IgM from the wells into the agar gel. Exactly equal volumes of an IgM standard, concentration $450 \mathrm{mg} . / 100$ ml., and synovial fluid from an autopsy control with an apparent IgM concentration of $20 \mathrm{mg}, / 100 \mathrm{ml}$. were well mixed. Quantitation of the IgM content of the mixture was carried out in duplicate as described above and the values of 240 and $248 \mathrm{mg}$. $/ 100 \mathrm{ml}$. obtained were compared with the predicated concentration of 235 $\mathrm{mg} . / 100 \mathrm{ml}$. It was concluded that IgM estimations were not significantly altered by the presence of synovial fluid.

\section{Patients}

Six patients (Table I) with moderate or severe rheumatoid arthritis and unilateral or bilateral chronic knee effusions were chosen. All had been taking oral aspirin for many weeks and three were receiving gold therapy. One patient was receiving a very small dose of prednisone orally. The volume of the effusions, estimated clinically before each study by one of us (R.B.), ranged between 20 and $125 \mathrm{ml}$. Patients were given $180 \mathrm{mg}$. potassium iodide three times daily by mouth, starting 2 days before and then continuing throughout the period of study.

Cases 1 to 5 received trace-labelled proteins intravenously, and plasma and synovial fluid samples were taken at regular intervals for estimation of radioactivity. Synovial fluid samples were aspirated from the knee after local anaesthesia and great care was taken to ensure complete sterility. Case 6 received an intra-articular injection of the labelled proteins and frequent blood samples were obtained. Continuous 24-hr urine collections were made during the studies of cases 1 to 4 .

Radioactivity in blood, synovial fluid, and urine specimens was measured in an autogamma well-type scintillation counter against appropriate standards. Mixtures of ${ }^{125}$ I and ${ }^{131}$ I were separated by pulse-height analysis, with appropriate corrections for ${ }^{131}$ I counts at the ${ }^{125}$ I photopeak.

More than 98.6 per cent. of the radioactivity in the patients' serum and more than 99.0 per cent. of the synovial fluid radioactivity was precipitable by TCA.

\section{Analysis of Radioactivity Curves}

Radioactivities (counts $/ \mathrm{ml} . / 100 \mathrm{sec}$ ) in plasma and synovial fluid were plotted against time and expressed as percentages of the initial plasma radioactivity (counts/ $\mathrm{ml} . / 100 \mathrm{sec}$.); this initial value was the radioactivity in the plasma 15 minutes after intravenous injection.

The plasma radioactivity curves for ${ }^{125} I$ or ${ }^{131} I$ labelled proteins could be resolved graphically into two or three exponential functions and were analysed by the method of Matthews (1957). Using this technique and accepting certain assumptions and limitations inherent to it (Freeman and Matthews, 1958), the following information was obtained:

(1) The fractional catabolic rate (FCR) or the percentage of the plasma radioactivity disappearing per day.

(2) The number of extravascular compartments in equilibrium with the plasma (usually only one) and the distribution of radioactivity between the compartments expressed as a fraction:

\section{IVC (Intravascular component) \\ EVC (Extravascular component)}

(3) The synthesis rates for IgM during steady rate conditions calculated by the formula:

$$
\frac{\text { Synthesis Rate }}{(\mathbf{m g} \cdot / \mathrm{kg} \cdot / \text { day })}=\text { FCR } \times \frac{\text { Total Plasma IgM (mg.) }}{\text { Weight }(\mathbf{k g .})}
$$

TABLE I

CLINICAL AND SEROLOGICAL DATA OF RHEUMATOID PATIENTS STUDIED

\begin{tabular}{|c|c|c|c|c|c|c|c|c|c|c|c|c|}
\hline Case No. & $\begin{array}{c}\text { Age } \\
\text { (yrs) }\end{array}$ & Sex & $\begin{array}{c}\text { Duration } \\
\text { of Disease } \\
\text { (yrs) }\end{array}$ & $\begin{array}{l}\text { Severity* } \\
\text { (I-III) }\end{array}$ & $\begin{array}{l}\text { Main Joints } \\
\text { Involved }\end{array}$ & $\begin{array}{l}\text { Treatment at } \\
\text { Time of Study }\end{array}$ & $\begin{array}{l}\text { Packed } \\
\text { Cell } \\
\text { Volume }\end{array}$ & $\begin{array}{c}\text { Enthro- } \\
\text { cyte } \\
\text { Sedimen- } \\
\text { tation } \\
\text { Rate }\end{array}$ & Latex & $\begin{array}{c}\text { Differ- } \\
\text { ential } \\
\text { Aggluti- } \\
\text { nation }\end{array}$ & $\begin{array}{c}\text { Anti- } \\
\text { Nuclear } \\
\text { Factor }\end{array}$ & $\begin{array}{l}\text { Volume } \\
\text { (ml.) of } \\
\text { Effusion of } \\
\text { Knee Joint } \\
\text { Studied }\end{array}$ \\
\hline 1 & 62 & $\mathbf{M}$ & 25 & III & $\begin{array}{c}\text { Knees and } \\
\text { hands }\end{array}$ & Aspirin & 37 & 70 & + & $1: 32$ & Neg & $\begin{array}{|ll|}\text { Left } & 125 \\
\text { Right } & 125 \\
\end{array}$ \\
\hline 2 & 58 & $\mathbf{F}$ & 5 & III & $\begin{array}{l}\text { Knees and } \\
\text { synovial } \\
\text { sheaths of } \\
\text { wrists }\end{array}$ & Aspirin Gold & 37 & 40 & + & $1: 28$ & Neg & 40 \\
\hline 3 & 56 & $\mathbf{M}$ & 2 & III & $\begin{array}{l}\text { Very wide- } \\
\text { spread: } \\
\text { many joints }\end{array}$ & Aspirin Gold & 38 & 44 & + & $1: 16$ & $\mathrm{Neg}$ & 40 \\
\hline 4 & 33 & $\mathbf{M}$ & 1 & II & $\begin{array}{c}\text { Knees, wrists, } \\
\text { and hands }\end{array}$ & Aspirin Gold & 36 & 50 & + & $1: 16$ & $\mathrm{Neg}$ & 20 \\
\hline 5 & 58 & $\mathbf{M}$ & 12 & II & $\begin{array}{l}\text { Knees and } \\
\text { hands }\end{array}$ & $\begin{array}{l}\text { Aspirin } \\
\text { Prednisone }\end{array}$ & 36 & 42 & + & $1: 64$ & $\mathrm{Neg}$ & 40 \\
\hline 6 & 62 & $\mathbf{M}$ & 2 & II & Knees only & Aspirin & 44 & 50 & + & $1: 256$ & $\mathrm{Neg}$ & 60 \\
\hline
\end{tabular}


(4) The catabolic rate was also calculated from the total radioactivity excreted daily in the urine as ${ }^{125}$ I or 131I inorganic iodide (Pearson, Veall, and Vetter, 1958). The percentage of the original dose of radioactivity appearing in the urine per $24 \mathrm{hrs}(\mathrm{U})$, divided by the mean plasma radioactivity for that $24-\mathrm{hr}$ period $(\mathrm{P})$, remains approximately constant, so that:

$$
\text { Catabolic Rate }(\%)=\left(\text { mean) } \frac{U}{\mathrm{P}} \times 100\right.
$$

The catabolic rate and the fractional catabolic rate should be similar if all the radioactivity is excreted in the urine and urine collection is complete.

\section{Results}

Studies lasting for 10 to 15 days were carried out on Cases 1 to 4 and short-term experiments on Cases 5 and 6. The results of these two groups of experiments are presented separately.

\section{IgM and Albumin Metabolism}

Table II summarizes the metabolic data relating to the first four patients. Plasma volumes were within the range 45.8 to $52 \cdot 2 \mathrm{ml} / \mathrm{kg}$., values which are compatible with the slight anaemia present. Examination of the plasma radioactivity curves (Figs 1 and 2) suggests that equilibration of the labelled IgM and albumin with the extravascular compartments was complete 70 to 90 hours after injection; and, after equilibration, IgM and albumin radioactivities declined as single exponentials apparent as straight lines on semi-logarithmic paper. The half-disappearance time $\left(t_{\frac{1}{t}}\right)$ of the IgM preparations varied from 4.46 to 7.95 days with corresponding fractional catabolic rates of $12 \cdot 1$ and $20 \cdot 8$ per cent. These catabolic rates were within

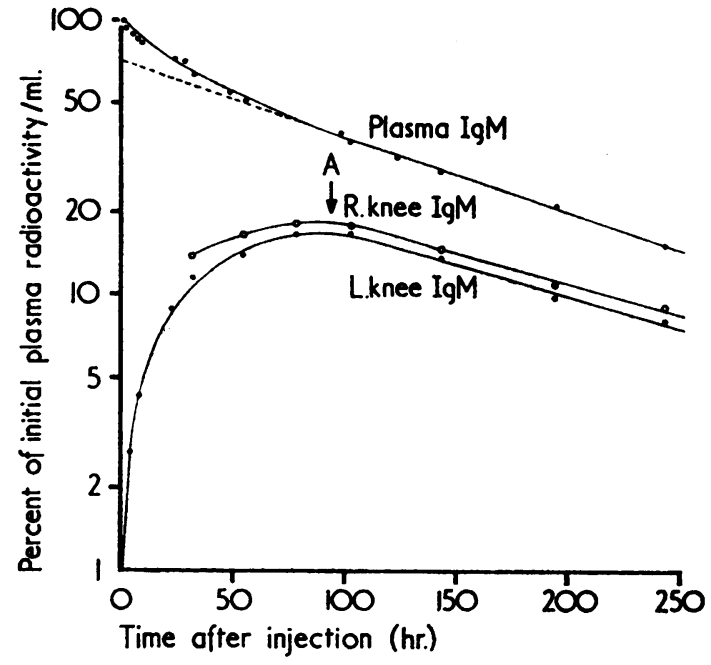

Fig. 1.-Plasma and synovial fluid radioactivity curves obtained from the study of Case 1. Equilibration between the plasma and synovial fluid occurred when the synovial fluid radioactivity curves reached their peaks (A).

the range of those found for the same IgM preparations in normal controls (Brown and Cooper, in preparation).

The synthesis rates of $4 \cdot 1$ to $6.6 \mathrm{mg} . / \mathrm{kg}$./day were also similar to those found in normal controls. 75 to 90 per cent. of the labelled IgM remained in the intravascular space, except for Case 3. Analysisō of his plasma radioactivity curve (Fig. 3) showed evidence of a third exponential, $b_{3}$, during the first 40 to 50 hours after injection. The $U / P$ ratio was constant during the 10 days of study, making it unlikely that denaturation of a fraction of the iodinated IgM led to early elimination. Analysis of the

TABLE II

METABOLIC DATA ON CASES 1 to 4

\begin{tabular}{|c|c|c|c|c|c|c|c|c|c|}
\hline Case No. & $\begin{array}{l}\text { Protein(s) } \\
\text { Injected }\end{array}$ & $\begin{array}{c}\text { Plasma Vol. } \\
\text { (ml.) }\end{array}$ & $\underset{(\mathrm{ml} . / \mathrm{kg} .)}{\text { Plasma Vol. }}$ & $\begin{array}{c}t_{t} \text { for Plasma } \\
\text { Radioactivity } \\
\text { Decay Slope } \\
\text { (days) }\end{array}$ & $\begin{array}{c}\text { Fractional } \\
\text { Catabolic } \\
\text { Rate } \\
\text { (percent./day) }\end{array}$ & $\begin{array}{c}\text { Intravascular } \\
\text { Extravascular } \\
\text { Distribution }\end{array}$ & $\underset{\text { Catabolic }}{\text { Rate U/P }}$ & $\begin{array}{c}\text { Serum IgM } \\
\text { Concentra- } \\
\text { tion } \\
(\mathrm{mg} . / 100 \mathrm{ml} .)\end{array}$ & $\begin{array}{c}\text { IgM } \\
\text { Synthetic } \\
\text { Rate } \\
\text { (mg./kg./day) }\end{array}$ \\
\hline 1 & IgM & 2600 & $48 \cdot 7$ & $4 \cdot 54$ & $19 \cdot 9$ & $\frac{80}{20}$ & $16 \cdot 4$ & 68 & $6 \cdot 6$ \\
\hline \multirow[t]{2}{*}{2} & IgM & 2440 & $48 \cdot 7$ & $7 \cdot 95$ & $12 \cdot 1$ & $\frac{74}{26}$ & $11 \cdot 4$ & 70 & $4 \cdot 1$ \\
\hline & Albumin & 2370 & $47 \cdot 5$ & $12 \cdot 1$ & $15 \cdot 4$ & $\frac{41}{59}$ & - & - & - \\
\hline 3 & IgM & 3400 & $52 \cdot 2$ & $5 \cdot 95$ & $18 \cdot 2$ & $\frac{66}{27}$ & $17 \cdot 7$ & 65 & $6 \cdot 2$ \\
\hline \multirow[t]{2}{*}{4} & IgM & 3080 & $47 \cdot 4$ & $4 \cdot 46$ & $20 \cdot 8$ & $\frac{77}{23}$ & $16 \cdot 4$ & 50 & 5.9 \\
\hline & Albumin & 2980 & $45 \cdot 8$ & $10 \cdot 38$ & $13 \cdot 7$ & $\frac{49}{51}$ & - & - & - \\
\hline
\end{tabular}

"Third Compartment (see text and Fig. 3) 


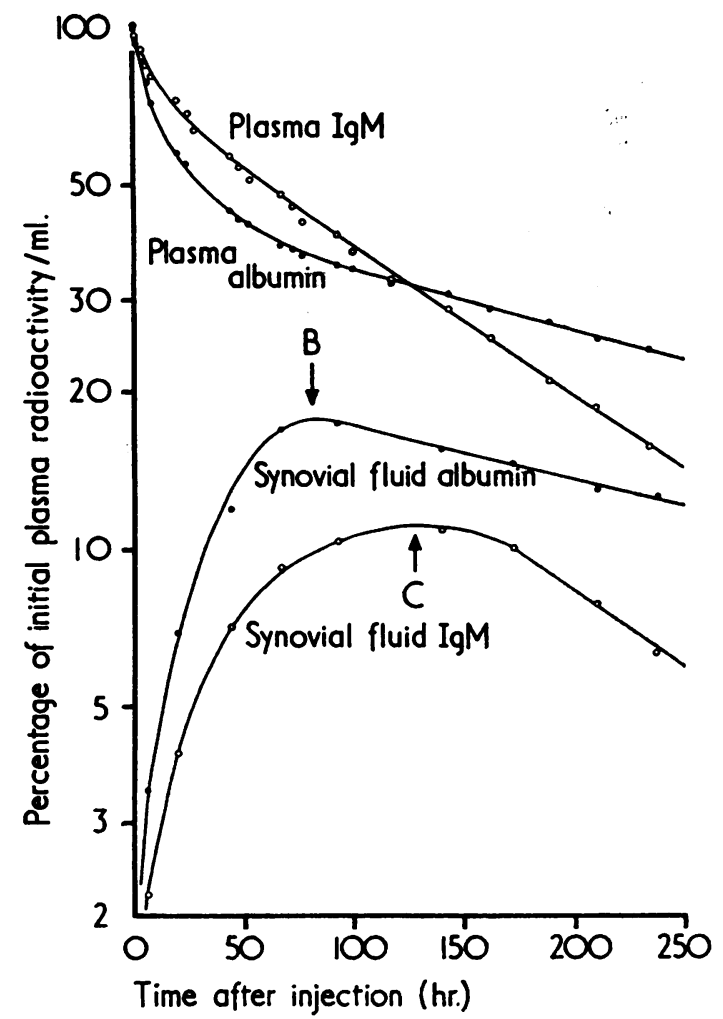

Fig. 2.-Plasma and synovial fluid radioactivity curves for IgM and albumin obtained from the study of Case 4 . The synovial IgM and albumin radioactivity curves appeared to equilibrate with their plasma radioactivity curves at $\mathbf{C}$ and $B$ respectively.

curves as a "three compartment system" by Matthews's method showed 7 per cent. of the injected protein in the third compartment, 27 per cent. in the extravascular space, and 66 per cent. in the plasma. This patient was the most severely affected with widespread joint involvement and many chronic effusions. It is possible that this compartment represents the expanded joint spaces, which accumulated sufficient radioactive protein to alter the plasma radioactivity curve during the first 40 to 50 hours.

In the two patients (Cases 2 and 4) who received labelled albumin in addition to labelled IgM, the $t_{\frac{1}{2}}$ for albumin was $12 \cdot 1$ and $10 \cdot 83$ days respectively. These values are lower than those usually reported (Rossing, 1967) for albumin ( $t_{\frac{1}{2}} 17$ days) in normal subjects.

\section{Synovial Exchange of IgM and Albumin (Table III)}

Case 1 had effusions in both knees. Samples were taken initially from the left knee only, then 32 hrs after injection sampling was continued from both knees. The radioactivity in each effusion rose steadily and equilibration between the plasma and

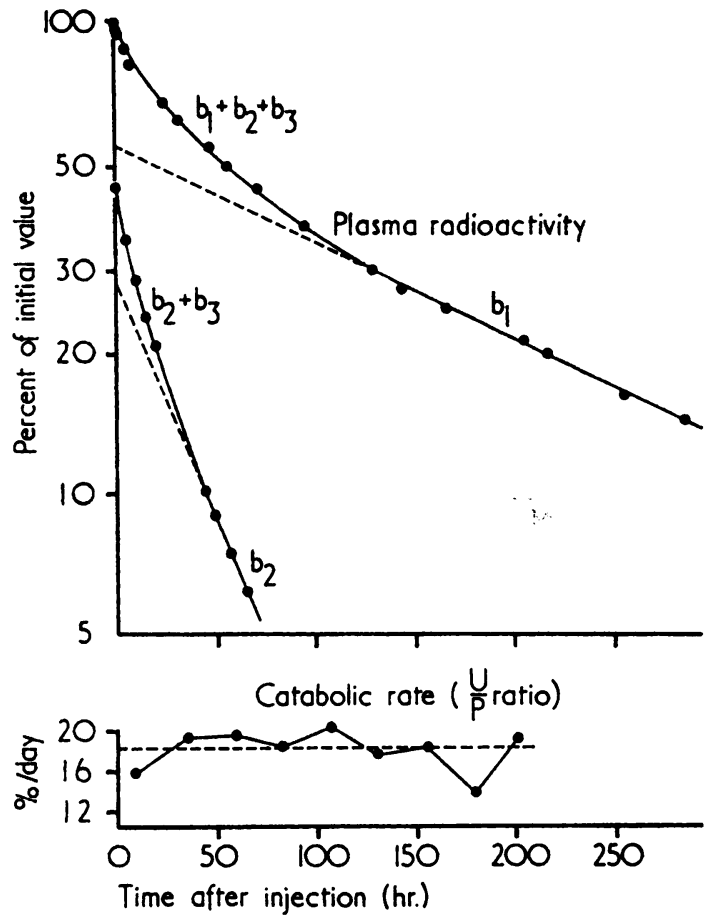

Fig. 3.-Plasma IgM radioactivity curve for Case 3 analysed by Matthews's method. $b_{1}$ is the exponential slope representing the catabolism of the protein from the plasma compartment. $b_{2}$ and $b_{2}$ represent the distribution of radioiodinated IgM into two extravascular compartments, one of which, $b_{2}$ is the extravascular space, and the other, $b_{3}$, is believed to be the joint-effusions in this patient.
The 24-hr U/P ratios are shown below.

each synovial fluid was thought to have occurred at $85 \mathrm{hrs}$ (A, Fig. 1). At this time the radioactivity per $\mathrm{ml}$. synovial fluid $\left(\mathrm{S}_{\infty}\right)$ was 0.46 and 0.42 of the plasma radioactivity per $\mathrm{ml}$. $\left(\mathbf{P}_{\infty}\right)$ for the right and left knee respectively. The synovial fluid activities then declined exponentially and their decay slopes $\left(t_{2} 5.00\right.$ and 5.63 ) remained approximately parallel to the plasma slope $\left(t_{\frac{1}{2}} 4 \cdot 54\right)$.

Fig. 2 illustrates the metabolism and distribution of iodinated IgM and albumin in Case 4. The synovial fluid IgM radioactivity appeared to equilibrate with the plasma 125 hours post-injection (C, Fig. 2) and then showed an exponential decline in parallel with the plasma IgM radioactivity. The $t_{\frac{1}{2}}$ for the synovial IgM was $5 \cdot 21$ days and for the plasma IgM 4.46 days. In contrast the synovial fluid albumin radioactivity equilibrated more rapidly with the plasma, reaching a maximum at $70 \mathrm{hrs}$ (B, Fig. 2) and the exponential decline of synovial fluid and plasma radioactivities $\left(t_{2} \quad 10 \cdot 8\right.$ days) was much slower than that of the IgM radioactivity.

Similar experiments were carried out on Cases 3 and 2 (see Table III, overleaf) and the results were similar to those described above. 
TABLE III

PLASMA-SYNOVIAL FLUID EQUILIBRIUM DATA

\begin{tabular}{|c|c|c|c|c|c|c|c|c|}
\hline \multirow[t]{2}{*}{ Case No. } & \multirow[t]{2}{*}{$\begin{array}{c}\text { Protein(s) } \\
\text { Injected }\end{array}$} & \multirow{2}{*}{$\begin{array}{c}\text { Time of Equili- } \\
\text { bration of } \\
\text { Plasma and } \\
\text { Synovial } \\
\text { Radioactivity } \\
\text { (hrs after } \\
\text { injection) }\end{array}$} & \multirow[t]{2}{*}{$\begin{array}{c}t_{ \pm} \text {from } \\
\text { Plasma } \\
\text { Decay Slope } \\
\text { (days) }\end{array}$} & \multirow[t]{2}{*}{$\begin{array}{l}t_{4} \text { from } \\
\text { Synovial } \\
\text { Fluid Decay } \\
\text { Slope } \\
\text { (days) }\end{array}$} & \multicolumn{2}{|c|}{$\begin{array}{l}\text { Ratios of Synovial to } \\
\text { Plasma Radioactivity at } \\
\text { Time of Equilibrium } \\
\qquad\left(\frac{\mathbf{S} \infty}{\mathbf{P} \infty}\right)\end{array}$} & \multicolumn{2}{|c|}{$\begin{array}{c}\text { Ratios of Synovial to Serum Protein } \\
\text { Concentration at Time of Equilibrium } \\
\frac{[\mathrm{S}]}{[\mathbf{P}]}\end{array}$} \\
\hline & & & & & IgM & Albumin & IgM & Albumin \\
\hline 1 & IgM & $\begin{array}{l}\text { Right knee } 85 \\
\text { Left knee } 85\end{array}$ & $4 \cdot 54$ & $\begin{array}{l}5 \cdot 00 \\
5 \cdot 63\end{array}$ & $\begin{array}{l}0.46 \\
0.42\end{array}$ & & $\begin{array}{l}0.41\left(\frac{28}{68}\right) \\
0.44\left(\frac{30}{68}\right)\end{array}$ & \\
\hline 2 & $\begin{array}{l}\text { IgM } \\
\text { Albumin }\end{array}$ & $\begin{array}{l}70 \\
20\end{array}$ & $\begin{array}{l}7 \cdot 95 \\
12 \cdot 1\end{array}$ & $\begin{array}{c}8 \cdot 25 \\
13 \cdot 2\end{array}$ & $0 \cdot 31$ & 0.39 & $0 \cdot 34\left(\frac{24}{70}\right)$ & $0 \cdot 62\left(\frac{1800}{2900}\right)$ \\
\hline 3 & IgM & 120 & 5.95 & $7 \cdot 45$ & 0.31 & & $0 \cdot 32\left(\frac{21}{65}\right)$ & \\
\hline 4 & $\begin{array}{l}\text { IgM } \\
\text { Albumin }\end{array}$ & $\begin{array}{r}125 \\
60\end{array}$ & $\begin{array}{r}4 \cdot 46 \\
10 \cdot 83\end{array}$ & $\begin{array}{r}5 \cdot 21 \\
10 \cdot 83\end{array}$ & 0.42 & $0 \cdot 52$ & $0 \cdot 48\left(\frac{24}{50}\right)$ & $0 \cdot 56\left(\frac{1550}{2750}\right)$ \\
\hline
\end{tabular}

*Actual protein concentrations indicated in $\mathrm{mg} . / 100 \mathrm{ml}$. in parenthesis as determined by the Mancini method.

The ratio of the synovial plasma radioactivities $\mathbf{S}_{\infty} / \mathbf{P}_{\infty}$ for either IgM or albumin at the point of equilibrium should represent the relative distribution of molecules between the two compartments if the trace-labelled material is indistinguishable from the patient's own protein. These ratios were obtained from the radioactivity per $\mathrm{ml}$. synovial fluid and plasma at the time of equilibration (Table III), and were compared with the synovial fluid to serum ratios $[\mathrm{S}] /[\mathrm{P}]$ obtained for total IgM and albumin by the Mancini method. There was close correlation between the two sets of ratios with the exception of the albumin ratios in Case 2.

In addition IgM and albumin ratios were obtained by the Mancini technique from the other patients in this study. These seven IgM and albumin ratios are compared in Fig. 4 with eleven IgM ratios and six albumin ratios obtained from similar paired autopsy control samples. The autopsy controls chosen had no known immunological disturbance or inflammatory joint disease. The rheumatoid IgM ratios ranged from 0.32 to 0.48 compared with 0 to 0.26 for the controls. The rheumatoid albumin ratios ranged from 0.56 to 0.81 compared with 0.21 to 0.68 for the controls.

\section{Rates of Synovial Exchange of IgM and Albumin}

The long-term experiments, described above, demonstrated a dynamic equilibrium between the plasma and synovial fluid for both IgM and albumin. However, these studies did not determine the relative rates of synovial transport of IgM and albumin.
In order to obtain information about these rates, $\frac{\Phi}{3}$ two short-term experiments were performed. In the first experiment, the rates of exchange from the plasma to the synovial fluid were compared, $\overrightarrow{0}$ injecting the labelled proteins intravenuously and

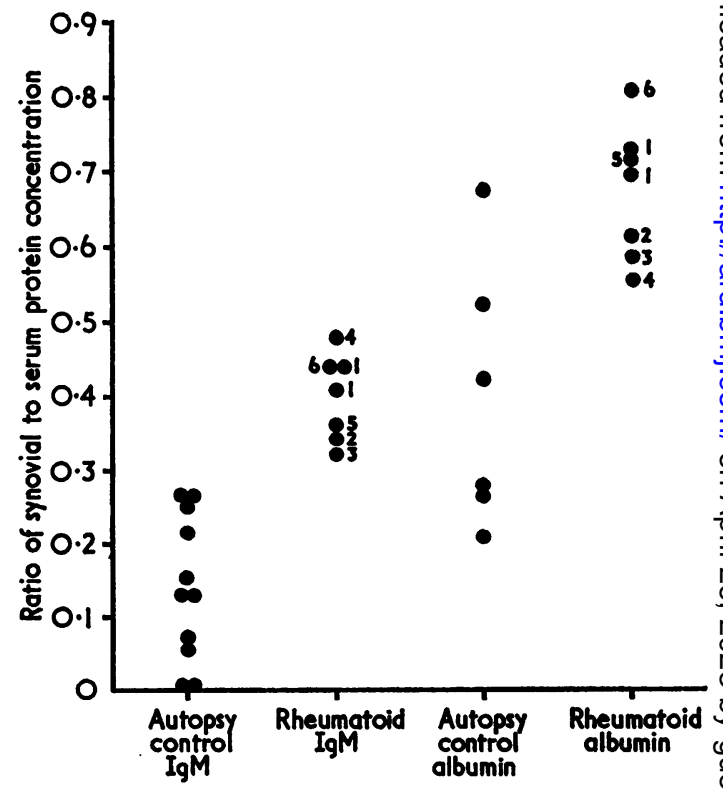

Fig. 4.-Synovial to serum IgM and albumin ratios determined by the Mancini method in six patients with rheumatoid arthritis and autopsy controls. Numerals indicate the patients in whom the metabolic and $T$ synovial exchange studies were carried out. 
then obtaining frequent synovial fluid samples for 2 hours. In the second experiment the rates of exchange from the synovial fluid to the plasma were compared by injecting the labelled proteins into a rheumatoid knee-effusion and obtaining frequent plasma samples for 2 hours. The rationale of such short-term experiments is that the rate of exchange of molecules from the injected compartment to the second compartment is approximately equal to the number of molecules which have accumulated at the end of the short period, since "re-flux" or re-entry into the injected compartment is unlikely to reach significant levels. By employing iodinated proteins one is able to compare the rates for IgM and albumin in one direction even though the patient's own IgM and albumin are passing in both directions under equilibrium conditions.

Fig. $5 a$ shows the result of a short-term experiment in Case 5, who received ${ }^{131} \mathrm{I}-\mathrm{IgM}$ and ${ }^{125} \mathrm{I}-$ albumin intravenously. Small synovial fluid samples were aspirated for 2 hours from a knee effusion estimated clinically to contain $40 \mathrm{ml}$. The radioactivity per ml. synovial fluid for each isotope is expressed as the percentage of the plasma radioactivity per $\mathrm{ml}$. at 60 minutes. The albumin radioactivity rose considerably faster than the IgM radioactivity. Thus by 60 minutes, the synovial fluid albumin radioactivity had reached a level of $3 \cdot 1$ per cent. of that present in the plasma, compared with $1 \cdot 2$ for the IgM. The absolute rate of plasma to synovial fluid transport in terms of $\mathrm{mg}$./ $\mathrm{hr}$ would be much greater for albumin than for IgM, since the plasma concentration of albumin is much higher than that of IgM.

Fig. $5 b$ shows the result of the experiment in Case 6 who received an injection of ${ }^{125} \mathrm{I}-\mathrm{IgM}$ and ${ }^{131} \mathrm{I}$ - albumin into a rheumatoid knee-effusion, determined by isotope dilution to have a volume of $60 \mathrm{ml}$. The relative rates of exchange of the two labelled proteins into the plasma obtained from the counts per ml. plasma expressed as the percentage of the 60-minute synovial fluid counts were virtually identical. By one hour the radioactivity per $\mathrm{ml}$. plasma was 0.035 per cent. of the synovial level for albumin and 0.036 per cent. for IgM. These two short-term experiments suggest that the rheumatoid synovial membrane is much more discriminating between albumin and IgM in the direction of plasma to synovial fluid than it is in the opposite direction.

\section{Discussion}

This study has demonstrated the exchange of trace-labelled IgM and albumin between plasma and synovial fluid in rheumatoid arthritis. After intravenous injection of radioiodinated protein, there was a rapid increase in synovial fluid radioactivity followed by the establishment of a dynamic equilibrium state between the two compartments. IgM equilibrated 70 to 125 hours after injection, and albumin, when studied, considerably earlier. During the phase of exponential decline of plasma radioactivity representing the catabolism of each protein, the respective synovial fluid radioactivities declined in parallel. This parallelism of the decay slopes suggests the maintenance of a dynamic equilibrium state and it is probable that the distribution of the trace-labelled proteins reflects the distribution of the patient's own proteins. In support of this statement, there was a remarkably close correlation, with the exception of one albumin study, between the synovial fluid to plasma

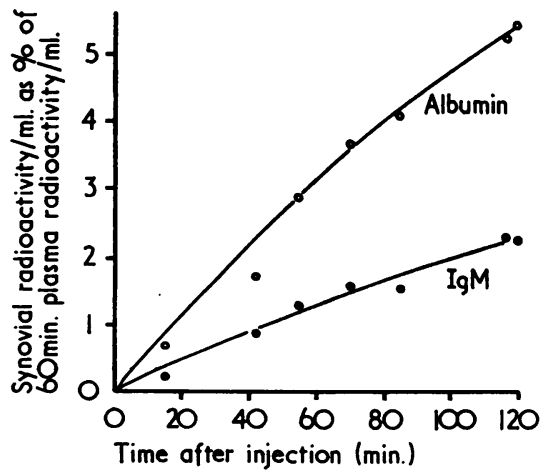

Fig. 5a.-Synovial fluid IgM and albumin radioactivity curves for Case 5 , showing the increase of synovial radioactivity during the first 2 hours after intravenous injection of radioiodinated IgM and albumin.

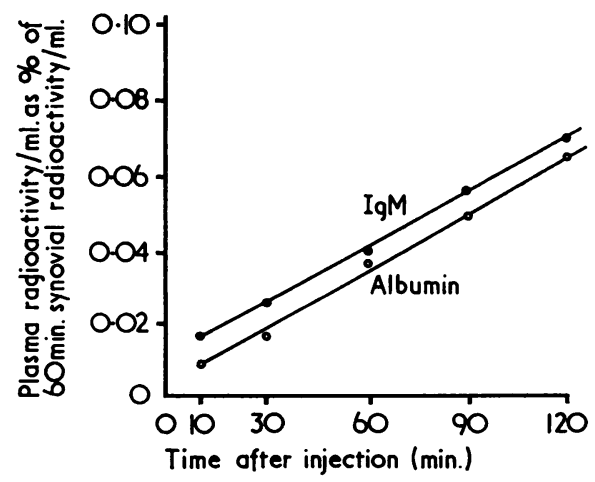

Fig. 5b.-Plasma IgM and albumin radioactivity curves for Case 6, showing the increase of plasma radioactivity during the first 2 hours after intraarticular injection of radioiodinated $\mathbf{I g M}$ and albumin. 
IgM and albumin ratios determined by the distribution of radioactivity $S_{\infty} / P_{\infty}$ and the distribution ratios for these proteins $[\mathrm{S}] /[\mathrm{P}]$ determined by the Mancini method (see Table III).

In effect this correlation between radioactivity and protein distribution ratios indicates that the specific activities (radioactivity/unit mass of protein) in plasma and synovial fluid are almost identical and that a true dynamic equilibrium has been reached.

From the patterns of the synovial fluid to plasma ratios as determined by the Mancini method (Fig. 4), the synovial membrane appears to be more permeable to albumin than to IgM. In rheumatoid arthritis the synovial fluid to plasma ratios are increased for both IgM and albumin compared with the autopsy controls. These results indicate that the permeability depends at least in part on molecular size, in both the normal and the rheumatoid groups.

It may well be that uncomplexed IgM rheumatoid factor also equilibrates between plasma and synovial fluid in a manner similar to the IgM in these studies. Whether this factor is synthesised locally in the synovial membrane, as suggested by the work of Smiley, Sachs, and Ziff (1968) and by Mellors, Nowoslawski, Korngold, and Sengson (1961), or synthesized at an extra-articular site in close proximity to the plasma compartment, it will, by analogy with IgM in this study, eventually equilibrate and be found in the synovial fluid and the plasma. Rapid synthesis of IgM rheumatoid factor in the synovial compartment would by dilution of labelled protein effectively lower the IgM-specific activity in the synovial fluid with respect to the plasma. However, we did not observe this dilution effect in relation to the chronic effusions studied here.

The short-term experiments on two rheumatoid patients (Cases 5 and 6 ) were carried out to determine the relative rates of exchange of IgM and albumin across the synovial membrane. The results of these experiments (Fig. $5 a$ and $5 b$ ) showed that, when IgM and albumin were injected intravenously, albumin appeared in the synovial fluid more rapidly than IgM in terms of their respective plasma con- centrations. When these proteins were injected into the synovial fluid they appeared in the plasma at a similar rate in terms of their respective synovial fluid concentrations. Similar results to these latter findings have been found for albumin and IgG by Rodnan and Maclachlan (1963).

Our results suggest that transport of proteins from synovial fluid to plasma is not selective in terms of molecular size, in contrast to the transport from plasma into synovial fluid. We do not know the explanation for this difference. Although a dynamic equilibrium exists between the two compartments, it is possible that the anatomical pathways for movement into and out of synovial fluid are different. It has been suggested (Hannestad and Mellbye, 1967) that passage of protein molecules from synovial fluid to plasma takes place via the lymphatics.

\section{Summary}

The exchange of IgM (cold agglutinin) and albumin between plasma and synovial fluid was studied in a small group of patients with rheumatoid arthritis using radioiodinated proteins. A dynamic equilibrium was established between plasma and synovial fluid 75 to $120 \mathrm{hrs}$ after intravenous ing $\vec{\oplus}$ jection for IgM and considerably earlier for ap bumin. This equilibrium was then apparent maintained. The synovial fluid to plasma ratios. as determined both from the radioactive studies and from the Mancini determinations of protein concentration, were higher for albumin than for IgM. The results of short-term experiments suggest that the rate of exchange of serum proteins into the synovial fluid is dependent on molecular size, whereas the rate of exchange in the opposite direction, from synovial fluid to plasma, is not.

The authors wish to thank Prof. J. V. Dacie and Prof. E. G. L. Bywaters for their advice and encouragement. We also thank Dr. D. Wright for his initial help with the labelling technique, and Mrs. Chantal Griffin and Miss Susan Francis for their valuable technical assistance.

\section{REFERENCES}

Ahlström, S., Gedda, P. O., and Hedberg, H. (1956). Acta rheum. scand., 2, 129 (Disappearance of radioactive serum albumin from joints in rheumatoid arthritis).

Barnett, E. V. Bienenstock, J., and Bloch, K. J. (1966). J. Amer. med. Ass., 198, 143 (Antinuclear factors in synovia).

Cooper, A. G. (1968). Clin. exp. Immunol., 3, 691 (Purification of cold agglutinins from patients with chronic cold haemagglutinin disease).

Freeman, T., and Matthews, C. M. E. (1958). Strahlentherapie, 38, 283 (The analysis of the behavior of ${ }^{131}$ I-albumin in the normal subject and nephrotic patients).

Hannestad, K., and Mellbye, O. J. (1967). Clin. exp. Immunol., 2, 501 (Rheumatoid factor in synovial effusions: local production and consumption). 
Helmkamp, R. W., Contreras, M. A., and Bale, W. F. (1967). Int. J. appl. Radiat., 18, 737 (I131_ labeling of proteins by the iodine monochloride method).

Kuipers, R. K. W., Francke, C., and Robert, W. N. (1956). Acta. rheum. scand., 2, 81 (Effects of antirheumatic drugs on the resorption of $\mathrm{I}^{131}$ labeled albumin from the synovial fluid).

Mancini, G., Carbonara, A. O., and Heremans, J. F. (1965). Immunochemistry, 2, 235 (Immunochemical quantitation of antigens by single radial immunodiffusion).

Matthews, C. M. E. (1957). Phys. in Med. Biol., 2, 36 (The theory of tracer experiments with ${ }^{131}$ Ilabelled plasma proteins).

McFarlane, A. S. (1963). J. clin. Invest., 42, 346 (In vivo behavior of $\mathrm{I}^{131}$ fibrinogen).

Mellors, R. C., Nowoslawski, A., Korngold, L., Sengson, B. L. (1961). J. exp. Med., 113, 475 (Rheumatoid factor and the pathogenesis of rheumatoid arthritis).

Oeff, K. (1960). In "Protides of the Biological Fluids: Proceedings of the 7th Colloquium, Bruges, 1959; ed. H. Peeters, p. 164. Elsevier, Amsterdam.

Pearson, J. D., Veall, N., and Vetter, H. (1958). Strahlentherapie, 38, 290 (A practical method for plasma albumin turnover studies).

Pekin, T. J., and Zvaifler, N. J. (1964). J. clin. Invest., 43, 1372 (Hemolytic complement in synovial fluid).

Perlmann, G. E., Ropes, M. W., Kaufman, D., and Bauer, W. (1954). Ibid., 33, 319 (The electrophoretic patterns of proteins in synovial fluid and serum in rheumatoid arthritis).

Rodnan, G. P., Eisenbeis, C. H., and Creighton, A. S. (1963). Amer. J. Med., 35, 182 (The occurrence of rheumatoid factor in synovial fluid).

- and Maclachlan, M. J. (1960). Arthr. and Rheum., 3, 152 (The absorption of serum albumin and gamma globulin from the knee joint of man and rabbit).

Ropes, M. W., and Bauer, W. (1953). "Synovial Fluid Changes in Joint Disease". Harvard University Press, Cambridge, Mass.

Rossing, N. (1967). Clin. Sci., 33, 593 (The normal metabolism of 131I-labelled albumin in man).

Schmid, K., and MacNair, M. B. (1956). J. clin. Invest., 35, 814 (Characterization of the proteins of human synovial fluid in certain disease states).

Schur, P. H., and Sandson, J. (1963). Arthr. and Rheum., 6, 115 (Immunologic studies of the proteins of human synovial fluid).

Smiley, J. D., Sachs, C., and Ziff, M. (1968). J. clin. Invest., 47, 624 (In vitro synthesis of immunoglobulin by rheumatoid synovial membrane).

Sundblad, L., Jonsson, E., and Nettelbladt, E. (1961). Nature (Lond.), 192, 1192 (Permeability of the synovial membrane to glycoproteins).

Vaughan, J. H., Jacox, R. F., and Noell, P. (1968). Arthr. and Rheum., 11, 135 (Relation of intracytoplasmic inclusions in joint fluid leucocytes to anti- $\gamma \mathrm{G}$ globulins).

Wilkinson, M., and Jones, B. S. (1964). Ann. rheum. Dis., 23, 22 (Electrophoretic studies of synovial fluid proteins).

L'échange de IgM et de l'albumine entre le plasma et le liquide synovial dans la polyarthrite rhumatoïde

\section{RÉSUMÉ}

L'échange de IgM (l'agglutinine à froid) et de l'albumine entre le plasma et le liquide synovial a été étudié chez un petit groupe de malades atteints de polyarthrite rhumatoïde en se servant de protéines radio-iodées. Un équilibre dynamique a été établi entre le plasma et le liquide synovial 75 à 120 heures aprés l'injection intraveineuse pour l'IgM et beaucoup plus tôt pour l'albumine. Cet équilibre était alors apparemment maintenu. La proportion entre le liquide synovial et le plasma, determinée par des études radioactives et aussi par la méthode de Mancini pour la concentration protéique, était plus élevée pour l'albumine que pour le IgM. Les résultats des expériences à court terme suggèrent que le taux d'échange des protéines sériques vers le liquide synovial dépend de la grosseur moléculaire, mais non pas dans la direction contraire.
Intercambio de IgM y Albúmina entre Plasma y Fluido Sinovial en la Poliartritis Reumatoide

\section{Sumario}

El intercambio de IgM (aglutinina fria) y albúmina entre plasma y fluido sinovial fue estudiado en un pequeño grupo de pacientes con poliartritis reumatoide, empleando proteínas radioyodadas. Se estableció un equilibrio dinámico entre plasma y fluido sinovial, 75 a 120 horas después de la inyección intravenosa en el caso de la IgM, y considerablemente más temprano en el de la albúmina. El equilibrio fue mantenido luego aparentemente. Las proporciones entre fluido sinovial y plasma, determinadas tanto por los estudios radiactivos como por las determinaciones Mancini de concentración de proteína, eran mayores en el caso de la albúmina que en el de la IgM. Los resultados de experimentos de corto plazo sugieren que el promedio de intercambio de proteínas del suero en el fluido sinovial depende del tamaño de las moléculas, mientras que el promedio de intercambio en el sentido opuesto, es decir, de fluido sinovial a plasma, no depende de aquello. 